\title{
THE STRATEGY OF PT BANK RIAU KEPRI CAPEM FLAMBOYAN IN PREPARATION OF OIL PALM REPLANTING
}

\author{
Dedi Fernandes*), Lukman M. Baga**), and Amzul Rifin ${ }^{* *}$ \\ *) PT Bank Riau Kepri, Menara Dang Merdu Bank Riau Kepri \\ Jl. Jendral Sudirman No. 462 Pekanbaru, Pekanbaru 28156, Indonesia \\ **) Department of Agribusiness, Faculty of Economics and Management, IPB University \\ Jl. Agatis, IPB Dramaga Campus, Bogor 16680, Indonesia
}

\begin{abstract}
Rejuvenation of oil palm has decreasedcredit growth and savings of PT Bank Riau Kepri Capem Flamboyan which may reduce the income. The paper aims to (1) identify constraints and opportunities of farmers related to the rejuvenation of oil palm plantations, (2) analyze external and internal factors, and (3) manage a development strategy of PT Bank Riau Kepri Capem Flamboyan on the rejuvenation of oil palm plantations. Qualitative analysis was used to identify constraints and opportunities related to replanting oil palm plantations. Furthermore, identification external and internal factors was used to conduct quantitative analysis using IFE and EFE matrix. The result shows that scores of IFE and EFE are 2.652 and 3.100, respectively. A a result the position of PT Bank Riau Kepri Capem Flamboyan in the IE matrix is at the second quadrant namely growth and development strategy. The IE matrix were use to formulate SWOT analysis, and resulted 16 alternative strategies. Strategic design to implement employed strategy architecture approach. the study concluded that the routine strategy of PT Bank Riau Kepri Capem Flamboyan is socialization with KUD, mediation between KUD and the government, appoinment KUD counterparts and improvement services to customers. The strategy was divided into three phases. The first is that the bank compete to get cooperation. The second is that rejuvenation begins, and the third period indicates that the oil palm start harvesting.
\end{abstract}

Keywords: EFE, IFE, replanting, strategy architecture, SWOT

\begin{abstract}
Abstrak: Peremajaan kelapa sawit mengakibatkan penurunan pertumbuhan kredit dan simpanan PT Bank Riau Kepri Capem Flamboyan sehingga mengurangi pendapatan. Tujuan penelitian adalah (1) mengidentifikasi kendala dan peluang petani terkait peremajaan kebun kelapa sawit, (2) menganalisis faktor eksternal dan internal serta (3) menyusun strategi PT Bank Riau Kepri Capem Flamboyan terhadap peremajaan kebun kelapa sawit. Analisis kualitatif digunakan untuk mengidentifikasi kendala dan peluang terkait replanting kebun kelapa sawit. Selanjutnya, mengidentifikasi faktor eksternal dan internal PT Bank Riau Kepri Capem Flamboyan dan melakukan analisis kuantitatif dengan mengunakan matriks IFE dan EFE. Hasil skor IFE sebesar 2.652 dan EFE 3.100 dihubungkan menggunakan matriks IE sehingga menempatkan PT Bank Riau Kepri Capem Flamboyan berada pada kuadran kedua yaitu strategi tumbuh dan berkembang. Hasil matriks IE merupakan rujukan merumuskan analisis SWOT sehingga didapatkan 16 alternatif strategi yang kemudian dirancang alur implementasi strateginya kedalam pendekatan arsitektur strategi. Hasil penelitianmenyimpulkan bahwa strategi rutin PT Bank Riau Kepri Capem Flamboyan yaitu sosialisasi dengan pihak KUD, menjadi mediasi antara KUD dan pemerintah, penunjukan tenaga pendamping KUD dan peningkatan layanan kepada nasabah. Strategi di bagi kedalam tiga tahap. Periode pertama adalah bank bersaing untuk mendapatkan kerja sama. Pada periode kedua adalah peremajaan mulai dilakukan, dan periode ketiga adalah perkebunan kelapa sawit mulai berproduksi.
\end{abstract}

Kata kunci: EFE, IFE, peremajaan, arsitektur strategi, SWOT

\footnotetext{
${ }^{1}$ Corresponding author:

Email: dedi011135@gmail.com
} 


\section{INTRODUCTION}

There are many oil palm plantations in Kampar Regency exceed the rejuvenation period (replanting) established by the Palm Oil Research Center (PPKS) in which the maximum planting age is 25 years. Astuti et al. (2018) and Niu et al. (2015) stated that the oil palms that reach economic age above 25 years should be rejuvenated since the height of the trees are more than 13 meters and make it difficult for the farmers to harvest. Acroding to Solikhin et al. (2012),factor affecting to rejuvenation is financial factor. The financial factor include high replanting cost, still productive oil palm plantations and reduced farmers' income. Another factor is no cooperation agreement between avalist companies and farmers. Moreover, Indrawati (2011) stated that relationship between plasma farmers and oil palm companies is not harmonious due to detrimental price of Fresh Fruit Bunches (FEB) for farmers, difficulty of the fruit selling system, land boundary issues, and existence of companies offering better service and higher price. These cause some cooperatives want to self-managed rejuvenation. According to Amalia et al. (2017), banks in conducting oil palm plantation rejuvenation cooperation require an avalis company. The high risk of self-managed rejuvenations makes farmers are hard to cooperate with the bank.

The government provides oil palm plantation rejuvenation grants of 25 million per hectare for farmers under the cooperatives or the Association of Farmers Groups (GAPOKTAN) through the Palm Oil Plantation Fund Management Agency (BPDPKS). Nurfatriani et al. (2019) stated that the grants are obtained frome Crude Palm Oil (CPO) endowment which is used to encourage farmers increasing quality and e sustainability of their plantations. Nonetheless, the grants cannot cover the amount of replanting cost, including farmers' daily living cost before plantations can be harvested. For instance, replanting cost of a plasma oil palm plantations in Tapung Hilir sub-district, Kampar regency, is 62 million per hectare (Yuliandari, 2018). In this condition, the role of bank is required to meet the shortfall of replanting cost. Nasution (2018) assumed that there are three conditions where farmers meet replanting cost: (1) BPDKS grant, farmers' saving, and bank loans, (2) BPDPKS grants and bank loan, (3) BPDPKS grants and farmers' savings in which the bank is as the custodian.
PT Bank Riau Kepri has made a policy No. 015/ KEPDIR/2018 about replanting agribusiness loans for farmers in cooperative or their group to meet replanting costs and self-managed replanting. PT Bank Riau Kepri has 16 Sub-Branch Office (Capem) and 12 stalls in which oil palm plantations as their market. One of the Sub-Branch Office is Flamboyan.

PT Bank Riau Kepri Capem Flamboyan has been cooperating with nine Village Unit Cooperative (KUD) to rejuvenate oil palm plantations. The cooperation will be stopped when rejuvenation is carried out, soloans realization and endowments from Third Party Funds (DPK) will be stopped. The total of loan for farmers is Rp 69.46 billion or $95 \%$ of total micro loan in which most of farmers are under KUD. There is a cooperation in DPK in terms of KUD production savings, payroll of farmers' income, replanting savings, and Qurban saving. Therefore, the bank needs to create a strategy from replanting oil palm plantation process to take opportunities and to keep the loan and DPK growth during the rejuvenation. In addition, PT Bank Riau Kepri Capem Flamboyan must be able to compete with other banks in maintaining the current markets and with the ones that have not cooperated yet. All this time, the loans for the oil palm farmers have often been carried out by financial institutions. There were some research findings that show loan schemes for farmers. Research of Nizar R et al. (2014) was dealing with granting loans scheme for the farmers in Muara Fajar, Rumbai subdistrict, Pekanbaru city. The findings indicated that loans scheme provided formal financial institutions for farmers, namely Savings and Loans Village Economic Business (UEK-SP) and Bank Rakyat Indonesia, and informal institutions namely cooperative and palm oil agency. Another study was conducted by Gumilang (2017) which aimed at explaining Islamic bank contracts for agriculture sector. The findings showed that suitable Islamic financial scheme for agriculture sector consist of salam contract scheme, istisna contract scheme, ijarah, ijarah mum tahiyah bit tamalik, musyarakah and mudharabah. These schemes are suitable with agriculture characteristics since they do not follow with certain interests, cooperation partners with profit loss sharing, and they fit the farmers in terms of goods fulfillment.

Another study was conducted by Mariyah (2018). Mariyah (2018) concluded that households' decisions to rejuvenate their oil palm plantations were affected 
byamount of land with different plant ages, farmers' ages, diversification of income sources, access to loans other than rejuvenating loans, length of education and total area of oil palm plantations. Besides, households' decisions to take oil palm rejuvenation loans were affected by farmers' ages, length of education, land area, household expenditure and household access to loans other than rejuvenating loans. The previous studies $t$ focused financing scheme for oil palm farmers and their perceptions toward tpreparation of oil palm plantations replanting. This study focuses on banking strategy to find out opportunity of replanting preparation in the oil palm plantations by using SWOT analysis and strategy of architectural design. This study describe internal and external condition of PT Bank Riau Kepri Capem Flamboyan toward oil palm plantation rejuvenation and map their strategy .

The study aims to (1) analyze constraints and the opportunities faced by farmers in replanting preparation, (2) analyze internal and external factors of the company, (3) formulate alternative strategies, and (4) arrange the bank strategy to prepare replanting of oil palm plantation.

\section{METHODS}

The study was conducted at PT Bank Riau Kepri Capem Flamboyan on 15 to 30 February 2020. The location was chosen by using purposive sampling since it is suitable to research object and target market ie., oil palm farmers. Data were collected through observation, interview, and Focus Group Discussion (FGD). Internal respondents of this study were employees of PT Bank Riau Kepri Capem Flamboyan, while external respondents were Plantation Department of Kampar Regency, Micro and Small Division of PT Bank Riau Kepri Capem Flamboyan, Board of KUD and oil palm farmers. Moreover, Secondary data were in the form of evaluation result reports, oil palm plantation planning, and policies from relevant agencies. Data analysis was divided into qualitative and quantitative. Qualitative analysis was carried out to identify constraints and opportunities of farmers in replanting oil palm plantations and internal and external factors of PT Bank Riau Kepri Capel Flamboyan. David (2009) stated that internal factor was analyzed in the form of management, marketing, financial, production or operation, and human resources. While, external analysis is competitors. Acording to Porter (1980), competing were divided into five factos including threat of new entrants, bargaining position of suppliers, bargaining position of buyers, competition among companies in the same industry, and threat of substitute products. Internal and external factors were presented in the Internal Factors Evaluation (IFE) and External Factors Evaluation (EFE) matrix analysis. The results of IFE and EFE matrix were combined with Internal and External (IE) matrix to create three main strategies, including growth and build strategy, hold and maintain strategy, as well as harvest and divest strategy (David, 2009).

The results of IE matrix were used to formulate alternative strategy using SWOT analysis. This analysis producesthree strategies including: (1) StrengthsOpportunities (SO) strategy by utilizing strengths of PT Bank Riau Kepri Capem Flamboyan to take advantage from the opportunities of oil palm plantation rejuvenation, (2) Weaknesses-Opportunities strategy creates a strategy which minimalizes all weaknesses of PT Bank Riau Kepri Capem Flamboyan to take advantage from the opportunities of oil palm plantation rejuvenation, (3) Strengths-threats

strategy creates a strategy by using the strengths of PT Bank Riau Kepri Capem Flamboyan in order to overcome any threats, and (4) Weaknesses-threats strategy creates a strategy by minimalizing any weaknesses and avoid any threats of PT Bank Riau Kepri Capem Flamboyan. Next phase is arranging the sequence of alternative strategy into specific period or time frames by architectural strategy approach. Yoshida (2006) stated that result of architectural strategy analysis could describe challenges and targets to be achieved. At the end, this analysis also illustrate overall condition of the bank in facing oil palm plantation replanting. The architectural strategy approach used $\mathrm{X}$ axis as a period of time and $\mathrm{Y}$ axis as the program strategy (Figure 1).

\section{RESULTS}

\section{Farmers' Constraint and Opportunities Oil Palms Replanting}

Identification to find farmers' constraints and opportunities in doing replanting preparation was employed through interview and FGD. Interview was conducted with nine board members of KUD, while FGD was conducted during the Annual Members Meeting 
(RAT) at KUD Raharja Tani Jaya and Manunggal Jaya with more than 100 farmers. FGD aims to strengthen interview result with KUD board members, so it can describe farmers' constraints and opportunities in oil palms replanting preparation. constraints are (a) high replanting cost, (b) land certificate issue, (c) cooperation agreement between avalist companies and farmers, (d) difficulty in completing requirements of bank and BPDPKS, (e) farmers' loans from other banks, and (f) location of plantation owner. Moreover, farmers' opportunities are (1) easy procedure of completing requirements from the government and BPDPKS, (2) availability of self-managed replanting loans alternative, (3) self-managed replanting improving farmers' income, and (4) farmer's activeness in KUD. Some research shows the same results related to constraints and opportunities facing farmers in the rejuvenation of palm oil plantation. According to Agustira et al. (2015) and Manurung et al. (2015), problem of farmers related to rejuvenation of oil palm plantations is related to high rejuvenation costs. According to Risman and Iskamto (2018), constraints of farmers are doing rejuvenation because farmers have loans in other banks so farmer's certificate is still guaranted in the bank. Meanwhile, Opportunity for farmers according to Nurfathiyah and Rendra (2019) is that active farmers in cooperatives are a prerequisite for getting assistance from the government and working with banks regarding the cost of replanting oil palm plantations.

\section{Analysis of Internal and External Factors of PT Bank Riau Kepri Capem Flamboyan}

Internal and External factor Analysis was used to identify factors affecting the banking in replanting preparation of oil palm plantation. It was presented in Internal Factors Evaluation (IFE) matrix and External Factors Evaluation (EFE) matrix. iIentification was done through interviews, FGD, and observation.. Table 1 describes internal factor evaluation matrixs.

The results of IFE matrix shows that trength factors of PT Bank Riau Kepri Capem Flamboyan toward the oil palm plantation replanting preparation. The most influencing item in strength factor is standardized and competent Human Resources, while the weaknesses factor is no special team to support KUD. Good quality of human resources will increase the performance of PT Bank Riau Kepri Capem Flamboyan. The weakness factor is related to no special KUD companion team. At this time, KUD desperately needs a companion in complementing requirements of banks and government related replanting oil palm plantations. According to Heryanto et al. (2018), farmer's factor in rejuvenation is knowledge of farmers, access to information, outreach activities, capital, income and farming experience. David (2009) concluded that regardless of the number of strengths and seaknesses, the highest score is 4.0 and the lowest score is 1.0 with 2.5 on average. Result of external factor analysis is presented in the Table 2 .

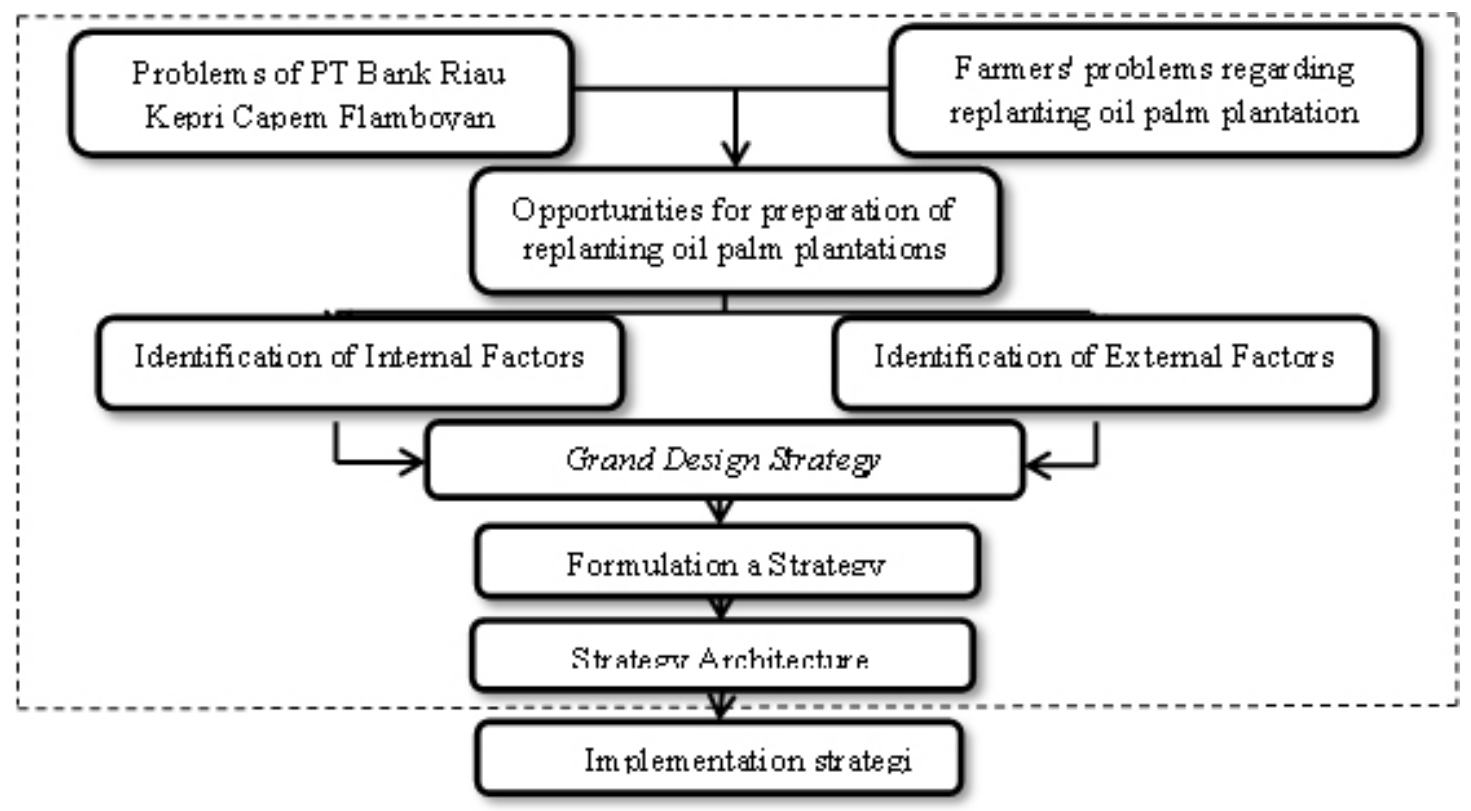

Figure 1. Research framework 
Table 1. Internal Factors Evaluation (IFE) Matrix

\begin{tabular}{lccc}
\hline Strength Factors & Value & Rating & Score \\
\hline Self-managed Loans & 0.080 & 3.333 & 0.226 \\
Standardized and competent Human Resources & 0.092 & 3.667 & 0.336 \\
Cooperation Policy with KUD & 0.083 & 4.000 & 0.333 \\
A Good relationship between the employees and the farmers & 0.067 & 3.667 & 0.245 \\
A local government bank & 0.069 & 3.667 & 0.255 \\
Strategic location & 0.066 & 3.667 & 0.242 \\
Good quality loans & 0.072 & 4.000 & 0.289 \\
\hline Weaknesses factors & & & \\
\hline Poor funding performance & 0.060 & 1.667 & 0.101 \\
No cooperation with oil palm companies & 0.069 & 1.333 & 0.092 \\
Higher risk of self-managed loans & 0.073 & 1.333 & 0.098 \\
Poor saving products of other banks & 0.068 & 1.667 & 0.113 \\
No special team to support KUD & 0.057 & 1.333 & 0.076 \\
No special saving product for replanting & 0.066 & 2.000 & 0.132 \\
Inexperienced employees & 0.079 & 1.000 & 0.079 \\
& 1.000 & 2.652 \\
\hline
\end{tabular}

Table 2. External Factors Evaluation (EFE) Matrix

\begin{tabular}{llll}
\hline Opportunity Factors & Value & Rating & Score \\
\hline High replanting cost & 0.068 & 3.000 & 0.203 \\
Good perception of farmers toward the replanting products & 0.087 & 3.667 & 0.319 \\
KUD commitment dealing with replanting savings & 0.086 & 4.000 & 0.344 \\
Government policy and BPDPKS & 0.068 & 3.000 & 0.203 \\
Unclear explanation of replanting loans from bank competitors & 0.066 & 3.333 & 0.220 \\
Some KUD will get funds of BPDPKS & 0.073 & 3.667 & 0.269 \\
Full support from head office of PT Bank Riau Kepri & 0.082 & 3.667 & 0.302 \\
\hline Threat Factors & & & 0.188 \\
\hline Replanting savings have many competitors & 0.071 & 2.667 & 3.000 \\
Avalist companies offer other banks & 0.069 & 0.206 \\
Some farmers are outside the city & 0.062 & 2.000 & 0.125 \\
Replanting loan guarantees are still under the first party's name & 0.056 & 2.333 & 0.130 \\
Slow economic growth in replanting location & 0.072 & 2.667 & 0.193 \\
High living cost of farmers & 0.071 & 3.000 & 0.212 \\
A bank loan is the last alternative & 0.070 & 2.667 & 0.186 \\
\hline
\end{tabular}

The results of the EFE matrix show that the highest opportunity factor for PT Bank Riau Kepri CAPEM Flamboyan for replanting oil palm plantations is KUD commitment related to replanting savings. According to Saputra et al. (2017), replanting of oil palm plantation funds through cooperatives collectively cooperate with banks. Savings replanting can survive until oil palm plantation which is in rejuvenation and number continues to grow every month. While the threat factor is the cost of living farmers increase. The high cost of living farmers is caused by lifestyle of farmers including increasingly consumptive and rising costs of fertilizer and maintenance of oil palm plantations. Hence, farmers ' income significantly decrease. The results of this research are further defined from previous research. According to Nwibo and Mbam (2013), constraints of farmers rejuvenate due to high consumption of farmers, lack of farming income, education level and nature of the agricultural products themselves. The total score is 3.100 which shows that company has a good response toward the Opportunities and the Threat. 


\section{Alternative Strategies of PT Bank Riau Kepri Capem Flamboyan}

PT Bank Riau Kepri Capem Flamboyan used Internal External (IE) and SWOT matrix analysis to formulation alternative strategies. IE matrix create general strategies by combining $X$ axis as total score of IFE matris and $Y$ axis as the total score of EFE matrix. Total score of IFE matrix of 2.652 and the total score of EFE matrix of 3.100 were combined, so it shows that position of PT Bank Riau Kepri Capem Flamboyan toward the oil palm plantation replanting preparation is in $2 \mathrm{nd}$ quadrant (Figure 2).

Based on IE Matrix, the position of PT Bank Riau Kepri Capem Flamboyan is in the second quadrant wich means growth and build strategy. Hence, the strategy emphasizes on the intensive strategy, including market penetration, market development, and product development (David, 2009). Market penetration strategy is trying to find a broader share market to improve loans and DPK. Besides, the banks focused on maintaining the existing share market and utilization various cooperation opportunities dealing with oil palm plantation rejuvenation. Market penetration was done by doing a more vigorous marketing efforts, improving services for the customer, and promoting. In addition, the second strategy is market development. Nowadays, most of share markets of PT Bank Riau Kepri Capem Flamboyan are oil palm farmers. Therefore, the rejuvenation process would affect loan growth and DPK. Here, the banks need to develop market outside of working area. Moreover, the third strategy is product development. The oil palm rejuvenation is a new thing faced by the banking. It is carried out to meet the farmers' needs in rejuvenation by adding benefits, characteristics, designs, and services of goods and services. PT Bank Riau Kepri Capem Flamboyan can develop products by adding the benefits and product services, while the head office can develop new products. Furthermore, general strategy becomes a reference to formulate a strategy by using SWOT analysis. Table 3 shows SWOT matrix of PT Bank Riau Kepri Capem Flamboyan.

\section{Strategy Map of PT Bank Riau Kepri Capem Flamboyan}

The architectural design strategy was used to provide a description of map strategy of PT Bank Riau Kepri Capem Flamboyan toward the oil palm plantation replanting. Design strategy was completed by mapping tchallenges and targets faced based on implemented period of time. Different condition in a period of time caused different challenges and targets. The architectural design strategy was illustrated by using two different axes. They were $\mathrm{X}$ axis and $\mathrm{Y}$ axis. $\mathrm{X}$ axis described a time frame consists of 1 st period to 2 nd period. While $\mathrm{Y}$ axis was a strategy program undertaken.

\section{The Sequence of Strategy Implementation}

Recommendation of the architectural design strategy of PT Bank Riau Kepri Capem Flamboyan toward the oil palm plantation replanting was divided into two strategies that consists of routine and gradual strategies. The routine strategy was carried out in each period, while gradual strategy was only done in one period. The routine strategy that was required to conduct socialization continuously. This was done to provide information for farmers dealing with the changes of government and banking policy, to improve the farmers' knowledge about new inventions of oil palm plantation, and to supervise the replanting activity. The next strategy is being a mediator between KUD and the government. The mediation was done regularly every stage of replanting, the farmers need full support from the government. In addition, the bank also appointed an employee as the assistant staff of KUD. It aimed to improve services provided for KUD by helping them to complete the requirements, to consult any issues, and to work as supervisor ensuring the success of replanting. The last routine strategy is improvement services for partner customers or the partners. This was done to improve loyalty of the partner to the bank so that a sustainable cooperation can be established.

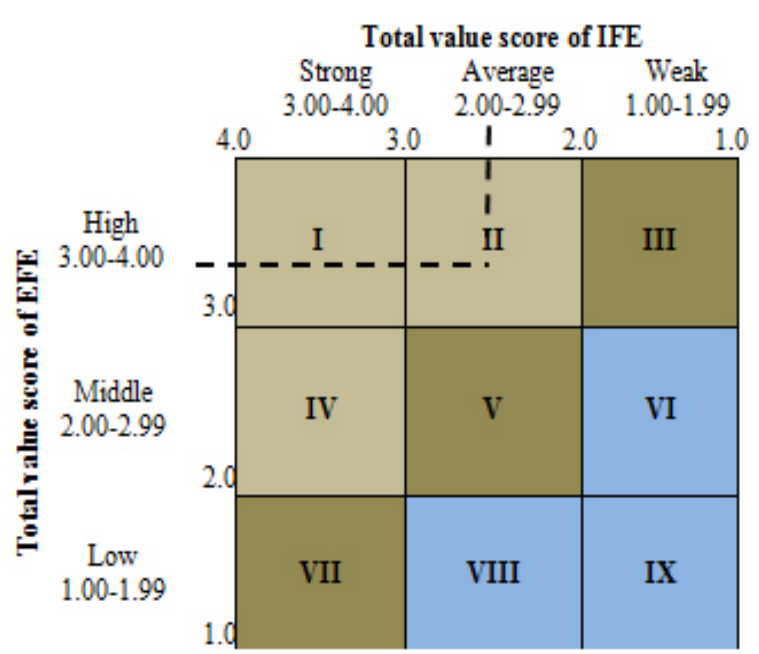

Figure 2. IE Matrix of PT Bank Riau Kepri CAPEM Flamboyan toward Replanting Preparation of Oil Palm Plantation 
Table 3. SWOT Matrix of PT Bank Riau Kepri CAPEM Flamboyan in facing replanting preparation of oil palm plantation

\begin{tabular}{|c|c|c|}
\hline & Strength (S) & Weakness (W) \\
\hline & $\begin{array}{l}\text { 1. Self-managed Loans } \\
\text { 2. Standardized and competent Human } \\
\text { Resources } \\
\text { 3. Cooperation Policy with KUD } \\
\text { 4. Agood relationship between the employees } \\
\text { and the farmers } \\
\text { 5. A local government bank } \\
\text { 6. Strategic location } \\
\text { 7. Good quality loans }\end{array}$ & $\begin{array}{l}\text { 1. Poor funding performance } \\
\text { 2. There is no cooperation with oil palm } \\
\text { companies } \\
\text { 3. Higher risk of self-managed loans } \\
\text { 4. Poor saving products of other banks } \\
\text { 5. There is no special team to support KUD } \\
\text { 6. Do not have special saving product for } \\
\text { replanting } \\
\text { 7. Inexperienced employees }\end{array}$ \\
\hline Opportunities (O) & Strategi S-O & Strategi W-O \\
\hline $\begin{array}{l}\text { 1. High replanting cost } \\
\text { 2. Good perception of farmers toward } \\
\text { replanting products } \\
\text { 3. KUD commitment dealing with } \\
\text { replanting savings } \\
\text { 4. Government policy and BPDPKS } \\
\text { 5. Unclear explanation of replanting } \\
\text { loans from bank competitors } \\
\text { 6. Some KUD will get funds of } \\
\text { BPDPKS } \\
\text { 7. Full support from center office of } \\
\text { PT Bank Riau Kepri }\end{array}$ & $\begin{array}{l}\text { 1. Cooperating with KUD to get funds of } \\
\text { BPDPKS (S1,S3,O2,O4,06) } \\
\text { 2. Mediating KUD and the government } \\
\text { (S4,S5,O4) } \\
\text { 3. Managing production funds of KUD } \\
\text { (S3,O2,O6) } \\
\text { 4. Improving services to the partners or the } \\
\text { partnership customers (S3, S6, O3, O6) } \\
\text { 5. Sustainability socializing with dengan } \\
\text { KUD (S1, S2, O4) } \\
\text { 6. Cooperating of all financial activity of } \\
\text { KUD (S2,S3,O3) }\end{array}$ & $\begin{array}{l}\text { 1. Giving recommendations to the center } \\
\text { office about special saving for replanting } \\
\text { (W1,W6,O3,O7) } \\
\text { 2. Giving technical training about oil palm } \\
\text { replanting (W7,O4,O7) } \\
\text { 3. Coordinating with center office to collaborate } \\
\text { with PKS (W2,O7) } \\
\text { 4. Supervising the success of replanting (W3,04) }\end{array}$ \\
\hline Threats $(\mathrm{T})$ & Strategi S-T & Strategi W-T \\
\hline $\begin{array}{l}\text { 1. Replanting savings have many } \\
\text { competitors } \\
\text { 2. Avalist companies offer other } \\
\text { banks } \\
\text { 3. Some farmers are outside the city } \\
\text { 4. Replanting loan guarantees are still } \\
\text { under the first party's name } \\
\text { 5. Slow economic growth in replanting } \\
\text { location } \\
\text { 6. High living cost of farmers } \\
\text { 7. A bank loan is the last alternative }\end{array}$ & $\begin{array}{l}\text { 1. Improving the distribution of loans for the } \\
\text { farmers individually (S6,S7,T7) } \\
\text { 2. Improving promotion dealing with } \\
\text { replanting loans (S1,S3,S5,T1,T2) } \\
\text { 3. Setting up loans scheme and Installment } \\
\text { payments (S1,S2,T5,T6,T7) }\end{array}$ & $\begin{array}{l}\text { 1. Supervising and monitoring the replanting loan } \\
\text { (W3,T3,T5,T6) } \\
\text { 2. Appointing some employees as KUD assistants } \\
\text { (W5,T2,T4) } \\
\text { 3. Promoting relevant saving products } \\
\text { (W1,W4,W6,T1,T2) }\end{array}$ \\
\hline
\end{tabular}

Moreover, the gradual strategy was divided into three periods. The first period was started now until 2022 or when the replanting process started. The first activity that can be carried out is a promotion of loans for replanting and saving product. It can be done simultaneously to save the time and the cost. Besides, in doing a promotion, a bank necessarily fixed any weaknesses by giving a recommendation of special saving for replanting and by coordinating with head office to collaborate with farmers' partner companies. This year, some KUDs would get funding from BPDPKS. This would be an opportunity for the bank to get farmers' trust. The bank is necessary having a cooperation with KUD as a pilot project to increase their trust and as a learning to improve services. The next strategy is to provide a training for the employees about the technical replanting of oil palm plantation. After having experience and knowledge, employees could be appointed as assistant staffs in KUD. The last strategy in this first period is to manage the production funds of KUD. The bank require to use opportunity to cooperate with KUD before rejuvenation process started by managing its production funds. In this period, the possible challenge faced is to improve employee's knowledge about replanting, the bank competition to get replanting cooperation and to improve services. The second period, the bank has cooperation and KUD has started replanting. This period estimated to begin in 2022 until 2026. It would be started by improving loans distribution for the farmers individually. It aims to maintain the loan growth during the replanting. The bank more often distributed loans collectively since there is a guarantee from KUD in installment payments., The firstis managing loans scheme and installment payment. The head office has given an authority to PT Bank Riau Kepri Capem Flamboyan to facilitate payment of replanting loans installments. Each branch office require to manage loan scheme and installment payment based on the estimated farmers' income after reducing their loving costs. 
The second strategy was carried out by monitoring the success of replanting process. Some of head office policies have been done to anticipate risks. One of which is regulation of plantation using consultants and executive contractors appointed by KUD and approve by the bank. Beside the available policies, PT Bank Riau Kepri Capem Flamboyan need to monitor the success of replanting by ensuring seeds used, and replanting process by the consultants and executive contractors appointed. The success of replanting would affect the success of farmers' loan installment payment. The next strategy is monitoring replanting loans. In this period, the bank should ensure that the payment was done on target. The bank should give loans gradually based on the condition of plantation and Budget Plans (RKA) made by KUD. In this condition, the possible challenge faced is to maintain the bank performance. The changes of giving loans for farmer individually and existence of self-managed replanting loans policy would cause loans risks. Another challenge is that the bank should ensure the success of replanting since this would affect loan payment. During this period, the target to be achieved is to improve loans and DPT during replanting of oil palm plantation.

The third period is a condition where bank has got the result of cooperation in the replanting of oil palm plantation. The plantation started to produce, and loan installment payment started to be carried out. This period estimated to begin in 2021 until 2047 or when the plantation is re-replanting. In this period, the strategy that can be done by the bank is having a cooperation with all financial activity at KUD. The bank must be able to see any opportunities of replanting, so the cooperation can be done again. This will give no space or opportunity for other banks to interfere the existing cooperation. The last strategy in this period is the same with the second period. It is to supervise and monitor the replanting loans. The difference is that supervision is done by ensuring payments from farmers to banks. The bank has cooperated with KUD to cut from production result of oil palm plantation based on the agreed agreements in contract. In this condition, the possible challenge faced by the bank is maintaining a good cooperation since some competitor banks have started to collaborate with KUD. The target to be achieved in this condition was to become a trusted bank to manage farmers' financial. Figure 3 shows strategy of architecture map of PT Bank Riau Kepri Capem
Flamboyan toward replanting preparation of oil palm plantation.

\section{Managerial Implications}

Recommendation of strategic design in this study is to minimize risks of oil palm plantation replanting cooperation, to identify any opportunities and to win the competition in replanting process. The strategy design was divided into three periods with different strategies and challenges in each period. It can describe the condition of PT Bank Riau Kepri Capem Flamboyan toward every stage of replanting.

PT Bank Riau Kepri Capem Flamboyan has tried to cooperate from the replanting process by implementing several strategies. They were improving services, mediating KUD and government, doing a promotion and minimizing existing weaknesses such as dealing with special replanting savings and cooperation with guarantor companies. While the risk of the cooperation was possibly avoided by monitoring, managing loans scheme, appointing assistant staffs, providing training for employees, and doing a continuously socialization. This cooperation is expected to avoid impact of reducing loans and DPK of PT Bank Riau Kepri during replanting, and to improve farmers' loyalty so that the existing opportunities in every financial transaction of KUD could be utilized by PT Bank Riau Kepri Capem Flamboyan.

\section{CONCLUSIONS AND RECOMMENDATIONS}

\section{Conclusions}

The findings of the study show that the threat faced by the farmers in replanting their plantation caused by high replanting cost, land certificate issues, the meeting point of cooperation agreement between avalist companies and farmers, the difficulty in completing requirements of bank and BPDPKS, farmers' loans from other banks, and location of the plantation owner. In addition, the opportunities for farmers in replanting their plantation are bigger since the requirements are increasingly easier for the government and BPDPKS.There is an alternative of self-managed replanting loans from the bank. This self-managed replanting loans could increase farmers' income and improve their activeness in KUD. 


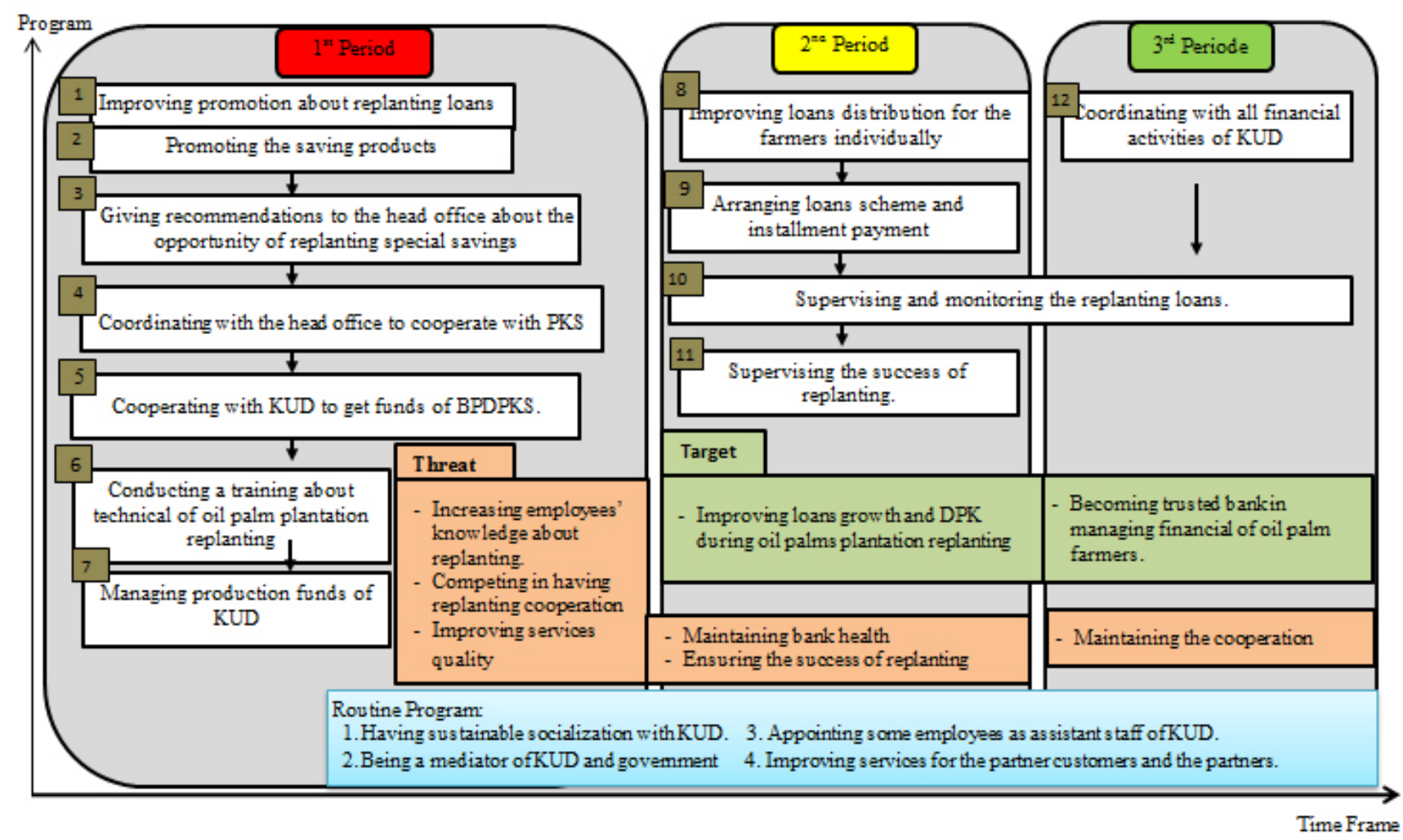

Figure 3. Architectural map strategy of PT Bank Riau Kepri CAPEM Flamboyan

From the identification of external and internal factors, it was obtained seven factors of Strengths, Weaknesses, Opportunities, and Threats toward replanting preparation. The result of identification shows that the bank is strong internally and has a good response to opportunity and threat. This could be seen from the value of factors which were above the average of 2.5. The result of IE matrix shows that PT Bank Riau Kepri capem Flamboyan was in 2nd quadrants of growth and build strategy

The recommendation strategy in this quadrant emphasize on the intensive strategy which are market penetration, market development, and product development. Thus, the strategy was formulated by using the SWOT matrix and obtained 16 alternative strategies which then were implemented into three periods of time. The first period described the condition where tPT Bank Riau Kepri Capem Flamboyan tried to win the competition to get the opportunity in each replanting preparation. The second period illustrate the condition in which the back has cooperated with KUD and started to replanting. The third period describe the condition where the plantation has started to produce and loan installment payment begins to be carried out. Each period has different challenges in implementing strategies. The main target to be achieved by PT Bank
Riau Kepri Capem Flamboyanis to improve loans growth and DPK during replanting and became trusted bank to manage oil palm farmers' financial.

\section{Recommendations}

The rejuvenation of oil palm plantation cam be conducted because of participation of Farmers, government, and banking. The banks take an important role in succeeding oil palm plantation rejuvenation. The bank could be a partner in financial planning for farmers, and the government partner as distributor of BPDPKS funds. This study was conducted on the strategy of PT Bank Riau KEPRI Capem Flamboyan toward oil palm plantations rejuvenation. However, the study could not represent the other banks' condition. Therefore, it needs other studies describe other banks' strategy toward oil palm plantations rejuvenation in other location.

\section{REFERENCES}

Agustira MA, Siahaan D, Hasibuan HA, 2019. Nilai ekonomi nira sawit sebagai potensi pembiayaan peremajaan kebun kelapa sawit rakyat. Jurnal Penelitian Kelapa Sawit 27(2):115-126. 
Amalia R, Nurkhoiry R, Nasution ZPS, Kurniawan A. 2016. Analisis kesiapan petani dan koperasi dalam program peremajaan perkebunan rakyat kelapa sawit (Studi kasus petani lingkup Ophir Kabupaten Pasaman Barat Provinsi Sumatera Barat). Jurnal Penelitian Universitas Riau 5(1):1-10.

Astuti YTM, Santosa TNB, Andi. 2018. Sistem penanaman legume cover crop pada lahan replanting perkebunan kelapa sawit. Jurnal Agroteknologi 2 (1):28-40.

David FR. 2009. Strategic management. Edisi Bahasa Indonesia. Dono Sunardi, penerjemah. Jakarta: PT Salemba Empat dan Pearson Education, Inc.

Gumilang RR. 2017. Model pembiayaan syariah bank muamalat untuk sektor pertanian. Jurnal Coopetition 8(2): 119-128.

Heryanto R, Murdy S, Aprolita. 2018. Faktor-faktor yang berhubungan dengan keputusan petani dalam peremajaan kelapa sawit di Kecamatan Sungai Bahar Kabupaten Muaro Jambi. Jurnal Universitas Jambi 1(1):1-11.

Indrawati H. 2011. Kajian tentang hubungan strategis produsen kelapa sawit di Kabupaten Pelalawan Provinsi Riau. Jurnal Pendidikan Ekonomi dan Bisnis 3(2):498-502.

Manurung LP, Hutabarat S, Kaswarina S. 2015. Analisis model peremajaan perkebunan kelapa sawit pola plasma di Desa Meranti Kecamatan Pangkalan Kuras Kabupaten Pelalawan Provinsi Riau. Jurnal Sorot 10(1):99-113.

Mariyah. 2018. Perilaku ekonomi rumah tangga petani dalam peremajaan kelapa sawit di Kabupaten Paser Kalimantan Timur [Disertasi]. Bogor: Institut Pertanian Bogor.

Nasution A. 2017. Analisis pembiayaan peremajaan kebun kelapa sawit rakyat kopermas tuah meusapat melalui dana skim hibah bpdp sawit Indonesia di Kabupaten Aceh Barat. Jurnal Bisnis Tani 3(1):26-37.

Niu F, Roll A, Meijide A, Hardanto A, Hendrayanto, Knohl A, Holscher D. 2015. Transpiration In an Oil Palm Landscape:Effects of Palm Age. Journal Biogeosciences 12(19):5619-5633.

Nizar R, Siswati L, Mufti. 2014. Kajian Ketersediaan Dan Pemanfaatan Kredit Untuk Petani Di
Kelurahan Muara Fajar Kecamatan Rumbai Kota Pekanbaru. Jurnal Perekonomian dan Bisnis 6(3):180-186.

Nurfathiyah P, Rendra. 2019. Penyuluhan tentang peremajaan kelapa sawit dan kelembagaan petani di Kecamatan Sungai Bahar Kabupaten Muaro Jambi. Jurnal Karya Abdi Masyarakat 3(1):86-94.

Nurfatriani F, Ramawati, Sari GK, Komarudin H. 2019. Optimization Of Crude Palm Oil Fund to Support Smallholder Oil Palm Replanting in Reducing Deforestation in Indonesia. Journal Sustainability 1(1):1-16.

Nwibo SU, Mbam BN. 2013. Determinants of savings and investment capacities of farming households in Udi Local Government Area of Enugu State,Nigeria. Research Journal of Finance and Accountin 4(15):59-68.

PorterME. 1980.StrategiBersaing: TeknikMenganalisis Industri dan Pesaing. Diterjemahkan oleh: Maulana A. Jakarta: Penerbit Erlangga..

Risman, Iskamto D. 2018. Analisis program replanting kebun kelapa sawit anggota KUD Makarti Jaya di Desa Kumain Kecamatan Tandun Kabupaten Rokan Hulu. Jurnal Riau Economic and Business Review. 9(2):84-93.

Saputra IMGD, Anggreni IGAAL, Dharma IP. 2017. Pola kemitraan usaha tani kelapa sawit kelompok tani Telaga Biru dengan PT Sawindo Kencana melalui koperasi di Kabupaten Bangka Barat Provinsi Bangka Belitung. Jurnal dan Agrowisata 6(2):249-258.

Solikhin, Fauzi AM, Purwadaria HK. 2012. Analysis of oil palm sustainable replanting models, a case at PT. Agrowiyana, Tunggul Ulu, Tanjung Jabung Barat, Jambi. Jurnal Manajemen dan Agribisnis 9 (Edisi Khusus):49-54.

Yoshida DT. 2006. Arsitektur Strategi: Sebuah Solusi Meraih Kemenangan dalam Dunia yang Senantiasa Berubah. Jakarta: PT Elex Media Kompetindo.

Yuliandari R. 2018. Pelaksanaan Manajemen Kemitraan PT Buana Wiralestari Mas dengan Petani Sawit Dalam Program Replanting Sawit di Desa Kijang Makmur Kecamatan Tapung Hilir. Jurnal Online Mahasiswa Fisip UNRI 5(1):1-15. 